\title{
Isolation, characterization and genes expression analysis of three dehydrin genes during cold acclimation of Eucalyptus globulus
}

\author{
Marta Fernández ${ }^{1 * \dagger}$, Sofia Valenzuela $2^{2^{*}}$ \\ From IUFRO Tree Biotechnology Conference 2011: From Genomes to Integration and Delivery \\ Arraial d'Ajuda, Bahia, Brazil. 26 June - 2 July 2011
}

Eucalyptus globulus is an important species for pulp production in Chile; however it has a high sensitivity to frost. During the last few years, many studies have directed their efforts to elucidate the molecular mechanisms that regulate plant response to cold stress through the analysis of gene expression. This work reports the isolation and characterization of coding and non coding sequence of three dehydrin genes of E. globulus which allowed comparing the gene expression of these genes during cold acclimation, the type of dehydrin and the presence of regulatory elements in their promoters which provided valuable information about the possible signaling pathways and regulation of these genes. The three dehydrins identified in E. globulus showed a high transcript accumulation in stem and leaf tissue of acclimated plants, compared to non-acclimated, and the highest transcript accumulation was observed after the exposition of plants to night frosts $\left(-2^{\circ} \mathrm{C}\right)$. Furthermore, the freezing resistant genotype exhibited a higher transcript accumulation after frost exposition compared to the sensitive genotype. These results support the idea that dehydrin proteins have an important rol during cold acclimation and frost tolerance in E globulus.

\section{Author details}

${ }^{1}$ Genómica Forestal S.A., Chile. ${ }^{2}$ Universidad de Concepción, Facultad de Ciencias Forestales. Centro de Biotecnología. Genómica Forestal S.A., Chile.

Published: 13 September 2011

\footnotetext{
* Correspondence: sofvalen@udec.cl

+ Contributed equally

${ }^{1}$ Genómica Forestal S.A., Chile

${ }^{2}$ Universidad de Concepción, Facultad de Ciencias Forestales. Centro de

Biotecnología. Genómica Forestal S.A., Chile

Full list of author information is available at the end of the article
}

doi:10.1186/1753-6561-5-S7-P81

Cite this article as: Fernández and Valenzuela: Isolation, characterization and genes expression analysis of three dehydrin genes during cold acclimation of Eucalyptus globulus. BMC Proceedings 2011 5(Suppl 7):P81.
Submit your next manuscript to BioMed Central and take full advantage of:

- Convenient online submission

- Thorough peer review

- No space constraints or color figure charges

- Immediate publication on acceptance

- Inclusion in PubMed, CAS, Scopus and Google Scholar

- Research which is freely available for redistribution

Submit your manuscript at www.biomedcentral.com/submit

\section{() Biomed Central}

\section{Biomed Central}

